\title{
Environmental taxation based integrated modeling towards sustainable environmental conservation approach
}

\author{
Abdul Qayum ${ }^{1}$, Anjana Gupta ${ }^{2}$, Akanksha Gupta $^{3 *}$ (I) and Rakesh Arya ${ }^{4}$
}

\begin{abstract}
Background: Globalization and rapid industrialization was inevitable during late nineteenth century considering the demand-supply deficit and requirements of evolving societies. However, at later stage these factors were mapped to be major reasons for the environmental pollution. Further, at the cost of environment degradation, development and economic growth cannot be achieved. The objective of the work is to design a green taxation policy to mitigate hazardous environmental impacts of various sectors and to visualize the benefits which can bridge the socio-economic divide prevalent, especially in developing nations. The approach is amalgamation of EIA based approach on the energy research institute criteria and environment-energy, economy.

Results: Integrated model is based on the principle that the tax rate has to be commensurate with the environmental damages which any project causes and it was found that both economic growth and environmental pollution are synchronous. Growth and development related projects cannot be compromised because of increased demands. Therefore, there has to be fine balance between development and conservation.

Conclusions: The policies may be designed on the model discussed to bring out optimal contribution of industry sector towards generating resources for economic growth and to bridge socio-economic divide. Green taxation proves to be deterrent tool towards environmental degradation and optimal energy utilization.
\end{abstract}

Keywords: De novo approach, Energy-economy-environment, Environmental conservation, Environmental impact assessment, Green taxation, Socio-economic growth

\section{Background}

It is widely argued that there is huge economic development pressure among developing nations to address increased need of the people, where resources are scarce (Narula and Dunning 2000). Scarcity compounds the pressure on environment due to maximal utilization of natural resources. And, India is not an exception as it is second most populous country in the world. As per an estimate, it is very likely to overpass China by 2040 to occupy the apex position in the population pyramid (McDevitt 1996). It is argued that energy consumption varies directly with population increase (John and

\footnotetext{
*Correspondence: akanks11_isj@jnu.ac.in

${ }^{3}$ Centre for West Asian Studies, Jawaharlal Nehru University, New Delhi, India

Full list of author information is available at the end of the article
}

Paul 1974). India will be under tremendous pressure to increase its energy demand to meet its overriding social and economic obligations due to burgeoning population. Therefore, environmental conservation by mitigating effects of various effluents and pollutants becomes inevitable. Taxation proved to be a deterrent towards reducing the energy demand by improving energy intensity. In Europe, fuel demand would have been twice if it had not followed the policy of high fuel taxation (Sterner 2007).

In European Union (EU), it was found that industries that reduce pollution increase its resource productivity and switch to renewable sources is highly encouraged. In Turkey, a second dividend of environmental taxation, that is economic benefits in addition to environmental improvements, shows potential when imported fuels are primary source of pollutant (Gurkan 2003). The concept 
of green taxation (GT) is often used on the place of environment taxation (ET) and vice versa. With incisive globalization, challenges have multiplied in functioning of all the government machinery. In particular, environment sector such as developmental and construction projects and its repercussion on the environment have gained much more attention and it is highly talked among the scientific community. The field has become voluminous and one of the essential determinants of ecological and economically viable development for any country.

Environment taxation policy in most of the developing nations is still in infant stage and it is in process of acquiring a laudable shape. India was the maiden country in Asia to introduce nationwide carbon tax of 50 rupees per ton (US\$ 1.07 per ton) on coal both produced and imported to India and it was re-iterated during the 10th Conference of Parties (CoP) meeting in 2010 (Mani 2013). However, the effect as a whole has not yet been quantified. The basic problem in quantification remains is the lack of accountability of all such old polluting vehicle and others including tax implementation related issues. At present, India stands at minimal performance in the international framework of environmental taxation but certainly it stands above the United States which has no concept of green tax (Fullerton et al. 2008). Under this circumstance, effective environmental taxation will be a decisive weapon to meet both global and local demands of environmental conservation. It will be a novice idea to enforce taxes on all those substances/activities which pollute or degrade the environment to bring a bottleneck on it. It is anticipated that taxation will have uncompromising deterrent effect on all existing pollution control measures and will be motivating to conserve environment and other natural resources.

European commission (EC) and organization for economic co-operation and development (OECD) in 2001 defined environment taxation as "a tax whose base is a physical unit of something that has specific negative impact on the environment" (Singh and Deshwal 2012). There needs to be an indigenous mechanism to curb environmental degradation. This is inadequate that taxation was designed merely on vehicular pollution and not on the various industries which are major contributor to environmental losses be in term of effluent discharge to the water bodies or to the atmosphere directly (Srivastava and Rao 2010). All industries engaged in hazardous waste generations must be made liable for the taxation and collected amount should be used for having effective environment conservation monitoring programs including awareness initiatives.

The incentive policy drawn in the schematic flowchart can be integrated with TERI based EIA to devise the tax liability for any project (Fig. 2). There cannot be same yard stick for all the industries for taxation, some cause minor damage while others may be catastrophic in nature e.g. noise pollution and nuclear waste leakage respectively. For progressive tax policies, tax laws have to be in an equitable and in fair manner. New technology needs to be used effectively to ensure taxes that industries owe to the government are paid on time. Green taxation proves to be an instrument in policy making in UK (Fullerton et al. 2008). It is widely argued by many environmentalist and renowned economists that pollution levies are an efficient instrument for environmental objectives (Baumol and Oates 1988). Both simulation models and practical experiences indicate that GT could be effective in reducing potential environmental impacts (Symons et al. 1994) and there is a visible impact of green shift in taxation (Srivastava and Rao 2010).

The de-novo approach developed in the current work is based upon environmental impact assessment (EIA) of a project based on the criteria established by the Energy and research institute (TERI), New Delhi (Qayum and Gupta 2014). TERI has developed "Green Rating for Integrated Habitat Assessment" system which is an evaluation tool and maintains a resource efficient built environment (GRIHA 2010). It evaluates environmental performance of a building holistically over its entire life cycle, thereby providing definitive standards for what constitute a 'green building. The scope of the current paper is restricted to tax incentive model for the effective mitigation of the environmental damage caused by the construction industry considering the limitation of TERI-GRIHA criteria. The global pressure acting inward and India's moral obligation to reduce the emission level makes this study much more relevant and it adopts integrated modeling by considering energy-economy-environment dynamics together of computable general equilibrium (CGE) model.

\section{Methods}

The presented model is primarily based on triad of environment-energy-economy (ENVEEM) model (Gurkan 2003) in conjunction with de-novo approach of environmental taxation. Former is dynamic CGE modeling based on interaction among the triads (Fig. 1) while the latter is formulation of integration of TERI guideline with proposed environmental taxation policy (Fig. 2). CGE is the principal analytical tool offered for conducting economic analyses of energy, economy and the environment. There exist two simultaneous equilibriums of 'government to producers' and 'producers to consumers' with surrounding parameters as in Fig. 1. In first equilibrium, supply of commodity and green tax imposition with revenue is an input from various sectors such as energy, technology matrix; intermediate goods etc. while in second equilibrium; supply of capital, labor and supply of commodities play a key variable role. ENVEEM model involves parallel interaction of consumer to government via producers, 


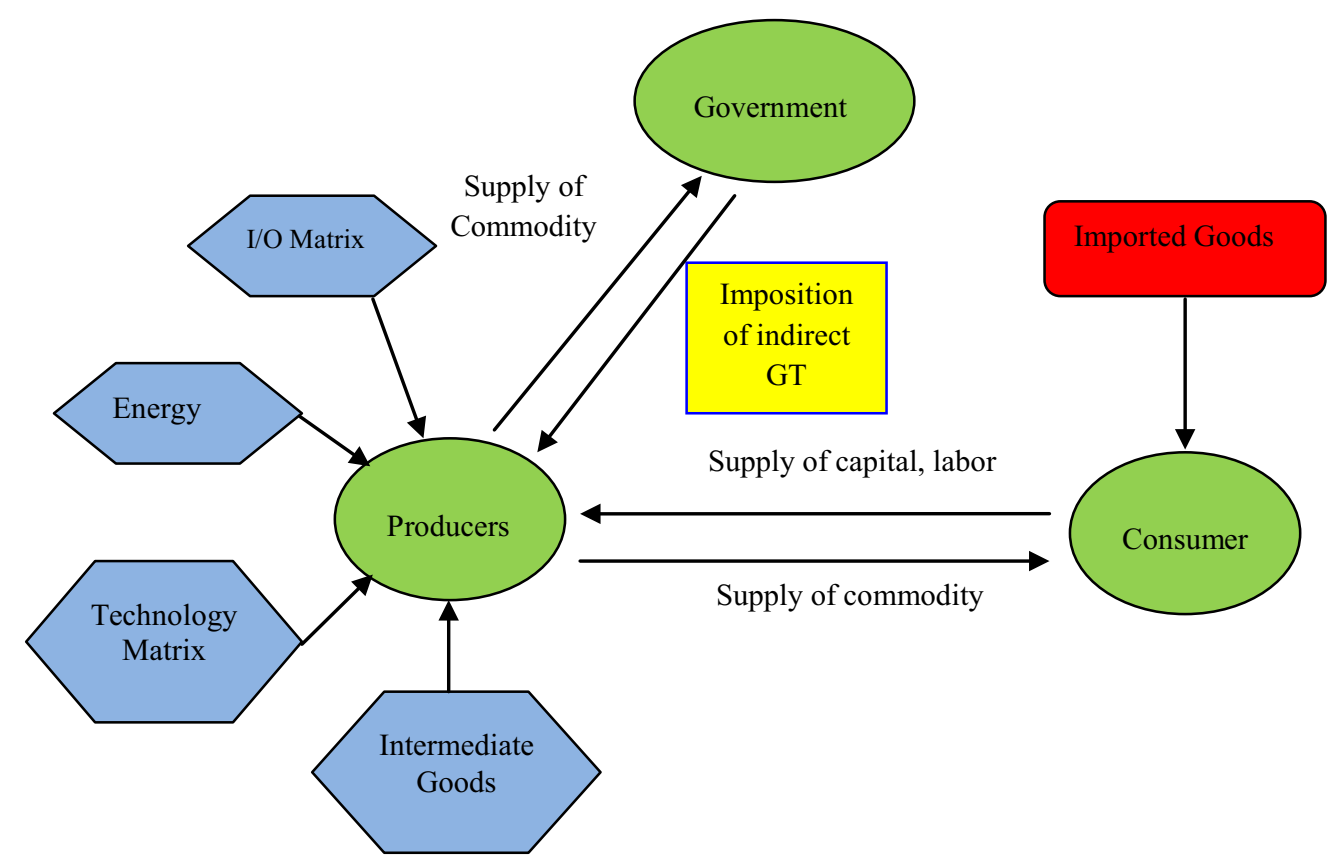

Fig. 1 ENVEEM model for imposition of indirect green taxes

while, producer is nerve center of the model incorporating numerous inflows and bidirectional flows from both consumer and the government epicenters. In the mean process, imposition of indirect green taxes comes into the picture from which TERI-based model evolves.

The energy research institute criteria are point based (total-106 and mandatory-30) and some are optional in nature. There is additional score (bonus) for covering these aspects of environmental conservation (Table 1). A schematic flowchart (Fig. 2) was developed for the taxation methodology and is derived from ENVEEM model (Fig. 1) which triggers The introduction of GT to stabilize the dynamic equilibrium of producer with the government while TERI-Model describes the detailed method of taxation for a particular industry. For a project, EIA is done using TERI criteria and it is evaluated against the environment damages it has caused or causes during and post construction phase. Percentage adherence of a project to the listed criteria is also estimated using a factor ' $x$ ' which was calculated as \% compliance of the project with TERI criteria of green building. Based on ' $x$ '; tax incentives are granted as per the schematic flowchart (Fig. 2). Revenue generated from additional GT (penalty) shall go to the socio-economic development and revenue from GT shall go to the 'Green Climate fund' for long term goals. This will collectively lead to better governance, sustainable growth targets, and will catalyze the endeavors for bridging the expanding socio-economic divides.

\section{How CGE model is applicable for India?}

The environment and climate change issues are not restricted to any geographical territory; rather it's a global issue. Moreover, Turkish economy is not much different from the Indian counterpart. Considering the issue to be global and without any specific Turkish economy parameters used in the CGE model, it can be extended to India as well without loss of any generality.

\section{How ENVEEM (CGM) model is connected with de-novo (TERI-based) approach?}

The model deals with the dynamic equilibrium of ENVEEM triads. Economic benefits are accrued because of adoption of efficient energy which leads to environment improvements. Prima facie, the blind industrialization at the cost of environmental damage contributes good economic benefit. It may be true in short term but this model fails miserably in long run and as post-industrialization ill effects are bigger dividends. The dynamic equilibrium must be accounted by considering long term sustainable environmental goals. Under this circumstance, green taxation shall be introduced as external variable to control indiscriminate use of natural resources for longer eco-viable benefits. It acts as a catalyst for producer-government equilibrium which in turn affects producer-consumer equilibrium, simultaneously. And, GT is also a key binding element for these two models towards developing the integrated approach. 


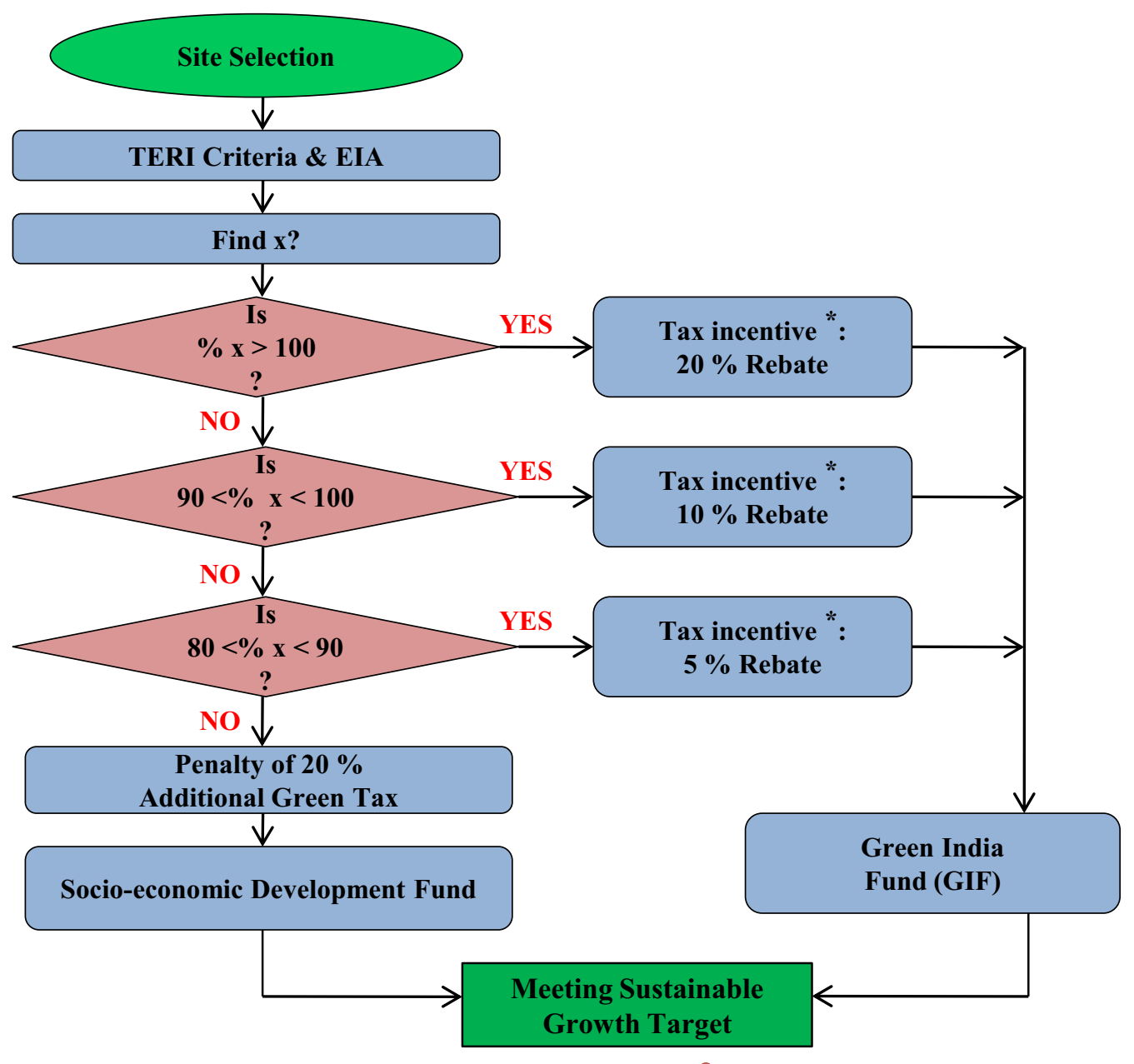

1. $x$ is \% compliance of project with TERI criteria

2. * Above criteria is based on empirical results

Fig. 2 Schematic flowchart for GT: de-novo approach, Source Qayum and Gupta (2014)

Linking of elementary models toward integrated approach Environment-energy-economy model offers holistic picture of various stake holders affecting energy-economy-environment dynamics and how introduced green taxation affects the related parameters while de-novo approach (Fig. 2) deciphers precise roadmap of taxation policy. The former explains why taxation needs to be introduced while latter explains how taxation policy has to be done for a particular industry (say construction) and its modalities. Moreover, without loss of generality it may be adopted for any other industry such as medical, transport etc. by including exhaustive list of criteria for evaluation of tax incentives based on percentage compliance with these criteria.

\section{Result and discussion}

Rating system of TERI-GRIHA

There are 34 criteria with 106 points in TERI-GRIHA rating system for a building to be declared a 'green building. These criteria cover wide range of aspects related to construction of a project site which impacts directly or indirectly the nearby environment (Table 1). Therefore, if these impact determinants are adequately addressed during and post-project operations, it will produce scintillating results in achieving objectives of environmental conservation without compromising the goals of economic development and aim of socio-economic uplift can also be ensured. A construction project has to be evaluated based on these criteria and points are given 
Table 1 TERI-GRIHA system of criteria based evaluation

\begin{tabular}{|c|c|c|c|c|c|c|c|}
\hline Criteria & Criteria detail & Points & Nature of criteria & Criteria & Criteria detail & Points & Nature of criteria \\
\hline 1 & Site selection & 1 & Partly mandatory & 18 & Renewable energy utilization & 5 & \\
\hline 2 & $\begin{array}{l}\text { Preserve and protect the land- } \\
\text { scape during construction } \\
\text { depository forestation. }\end{array}$ & 5 & Partly mandatory & 19 & $\begin{array}{l}\text { Renewable energy based hot } \\
\text { water system }\end{array}$ & 3 & \\
\hline 3 & $\begin{array}{l}\text { Soil conservation (till post con- } \\
\text { struction) }\end{array}$ & 2 & & 20 & Waste water treatment & 2 & \\
\hline 4 & $\begin{array}{l}\text { Design to include existing site } \\
\text { features }\end{array}$ & 4 & Mandatory & 21 & Water recycle and reuse & 5 & \\
\hline 5 & Reduce hard paving on site & 2 & Partly mandatory & 22 & $\begin{array}{l}\text { Reduction in waste during con- } \\
\text { struction }\end{array}$ & 1 & \\
\hline 6 & Enhance outdoor lighting system & 3 & & 23 & Efficient waste segregation & 1 & \\
\hline 7 & $\begin{array}{l}\text { Plan utilities efficiently y and } \\
\text { optimize on-site circulation } \\
\text { efficiency }\end{array}$ & 3 & & 24 & Storage and disposal of wastes & 1 & \\
\hline 8 & $\begin{array}{l}\text { Safety facilities for construction } \\
\text { workers }\end{array}$ & 2 & Mandatory & 25 & Resource recovery from waste & 2 & \\
\hline 9 & $\begin{array}{l}\text { Reduce air pollution during con- } \\
\text { struction }\end{array}$ & 2 & Mandatory & 26 & $\begin{array}{l}\text { Use of low VOC paints and } \\
\text { adhesives }\end{array}$ & 3 & \\
\hline 10 & $\begin{array}{l}\text { Reduce landscape water require- } \\
\text { ment }\end{array}$ & 3 & & 27 & $\begin{array}{l}\text { Minimize ozone depleting sub- } \\
\text { stances }\end{array}$ & 1 & Mandatory \\
\hline 11 & Reduce water use & 2 & & 28 & Ensure water quality & 2 & Mandatory \\
\hline 12 & $\begin{array}{l}\text { Efficient water use during con- } \\
\text { struction }\end{array}$ & 1 & & 29 & $\begin{array}{l}\text { Acceptable outdoor/indoor noise } \\
\text { level }\end{array}$ & 2 & \\
\hline 13 & $\begin{array}{l}\text { Optimize design to reduce energy } \\
\text { demand }\end{array}$ & 8 & Mandatory & 30 & Tobacco and smoke control & 1 & \\
\hline 14 & $\begin{array}{l}\text { Optimize energy performance } \\
\text { within specified comfort limits }\end{array}$ & 16 & & 31 & Universal accessibility & 1 & Mandatory \\
\hline 15 & $\begin{array}{l}\text { Utilization of fly ash in building } \\
\text { structure }\end{array}$ & 6 & & 32 & Energy audit and validation & 2 & Mandatory \\
\hline 16 & $\begin{array}{l}\text { Reduce volume, weight, and time } \\
\text { of construction by adopting } \\
\text { technology }\end{array}$ & 4 & & 33 & $\begin{array}{l}\text { maintenance protocol for mechan- } \\
\text { ical and electrical equipments }\end{array}$ & 2 & \\
\hline 17 & Low energy material in interiors & 4 & & 34 & Innovation (bonus) & 4 & \\
\hline
\end{tabular}

using Table 1. For 'innovation' criteria following 5 points could be used: 1. Alternative transportation, 2. Environmental education, 3. Company policy on green supply chain, 4. Life cycle cost analysis and, 5. Any other criteria proposed by the applicant for granting points for innovation criteria.

There are points corresponding to each criterion and some are mandatory while some are optional. A project firm may decide to cover all points and aim to achieve the optional criteria also. And, therefore it shall be benefited in terms of tax incentives on the material purchase or in the other forms. If green taxation policy is adopted, project should get advantage by having reduced taxation rates if it adopts environmental friendly methods and technology which are inherent trait of green taxation. Factor ' $x$ ' is calculated for any project. 102 points shall be covered by each project, while 4 points are bonus. Thus, $\mathrm{x}=$ [no of pointes earned/102] $\times 100$; which if exceeds 100 deserves a tax rebate incentive by $20 \%$ in the taxes payable to the government. However, if $\mathrm{x}<80 \%$, the organization shall be penalized $20 \%$ additional green tax i.e. 1.2 times of the payable tax and additional earned amount shall be dispensed to fund for improving socioeconomic divide while the usual tax remained after granting tax incentives shall be deposited to 'Green India Fund- GIF. These two funds taken together shall generate huge chunk of revenue which may be used for achieving sustainable growth targets.

Further, TERI criteria can be judged for its compliance and de-novo approach of taxation policy may be applied for any selected project. EIA is a tool that aims to ensure sustainable development through the evaluation of major activities such as policy, planning, program, or project which are likely to have significant environmental impacts. EIA is mandatory in India for all the major projects (total 30 projects of category A) after EIA notification of 1994. It commences immediately with submission of project details. EIA report provides clear information 
to the decision makers on the different environment pollution and degradation scenarios.

Integrated model has taxation incentive policy primarily based on the 'polluter pays principle.' All environmental degrading liability in form of green taxation must be borne by the producer at the source of origin itself and industries are primary source for the degradation caused but not by the consumers on downstream side. Further, the income generated from taxation shall not be used by the victims of the environment degradation but it shall be utilized towards GIF, which may also be used towards having environmental awareness campaigns, while the revenue earned through tax penalty shall be used towards narrowing down the socio-economic deprivation. This will act as precursor for thinking and to invent environment friendly techniques (say green techniques) for the industries to mitigate its impacts on the environment and to earn tax incentives. The implication of polluter pays lies in the economic obligation in relation to the potential environment damaging activities. The objective of taxation is the adoption of all those activities which optimally reduces the level of degradation as it is imperative that industries will try to save its tax money. The taxation policy will generate new hopes for optimizing profits by reducing the amount on the basic expenditures in form of tax incentives. Therefore, it is very likely that industries will bring environmental friendly measures and efficient technology base.

\section{Global scenario of green taxation}

With Kyoto Protocol and several other international treaties under UNFCCC many countries have undertaken binding and non-binding reduction targets of GHGs. It also provides various flexible mechanisms such as emission trading, CDM and joint implementation (JI). The parties to Kyoto can suitably utilize these mechanisms as per its needs. It helped in establishing carbon markets to promote emission trading system (ETS). EU-ETS is the world's first, largest and longest running ETS which has translated provisions of Kyoto Protocol into a reality, in some extent. World Bank forecasted long back that carbon financial markets possess enormous potential and it is going to be the biggest market. Further, it opened new gates for the trade in name of CDM and carbon credits. As consequence, by 2020 the whole world is much likely to witness a global reduction in emission of GHGs (United Nations framework convention on climate change 2011). With time, the tax base for the environmental tax has expanded. Several developed countries have sailed far ahead in imposing green taxation including the fuel taxes which are levied across various nations in Europe. Other taxes such as waste end tax exist in Austria, France, Finland, Greece, Sweden, UK and Norway while annual car tax differentiated according to environmental characteristics exists in Germany (Table 2).

\section{Situation of carbon trading in indian markets}

A developing and over populous country like India is a preferred location for carbon credit buyers. It is anticipated this developing nation is likely to earn at least US\$ 5-10 billion from carbon trading over a period of time (Nair and Nandakumar 2013). It is among the largest beneficiaries ( $31 \%)$ of carbon trade through the advent of clean development mechanism (CDM) and owns $17 \%$ trade in carbon credit globally (Fig. 3). Carbon is now traded on its multi commodity exchange mechanism and it is first exchange in Asia to trade carbon credits which came into existence under the purview of effective cleaning of the environment (Newell et al. 2012). At present, carbon market of India is one among fastest growing markets of the world and has earned carbon credits $\sim$ US\$ 30 million. India is a party to the Kyoto Protocol on climate change committing member countries to reduce their GHG emissions although it has no binding targets. India's compliance with the Kyoto requirements will most probably be on the agenda especially after advent of 'Green India Mission.'

\section{Green tax and constitutional provisions}

During the proposal of thirteenth finance commission in India, it was recommended for subjecting all environmental polluting goods to a non rebatable excise which is indeed a challenge in itself and attracts huge research work for quantifying it and on natural gases a final view was not taken so far. Further, commission recommended three specific grants for promoting environment with the aim of increasing the forest cover, better management of water resources and promoting connectivity of renewable energy to the national grid. It poses a promising picture for times to come and India is ready to join the leagues nations of 'environmentally sound. The word 'pollution' does not find any space in Indian constitution. However, it can be related to 'Public health' which comes in the State list and of the VIIth schedule and to 'Right to clean environment' which is integral part of Indian constitution under Article 21 (Protection of Life and Personal Liberty). Pollution control legislations are passed in the national interest under Article 249 of Indian constitution. The effective tax rates for selected polluting goods and industries was also studied to conclude the continuous increase and escalation effect over indirect taxes (Fig. 4).

There is huge hue and cry worldwide over climate change and environmental degradation, it's high time to translate various treaties and conventions into committed actions after ratifying it and implementing green taxation in principle can be achieved, globally. Different countries may have different carbon tax because they have 
Table 2 Impact of the green shift in taxation: selected international evidence

\begin{tabular}{|c|c|c|c|}
\hline Country and tax & Period evaluated & Impact & Source \\
\hline $\begin{array}{l}\text { Finland-energy and carbon } \\
\operatorname{tax}\end{array}$ & 1990-2005 & $\begin{array}{l}\mathrm{CO}_{2} \text { emissions } 7 \% \text { lower than would have otherwise been a shift from } \\
\text { carbon tax to output tax on electricity in } 1997 \text { may have lessened } \\
\text { impact }\end{array}$ & $\begin{array}{l}\text { Nordic council (2006) } \\
\text { Nordic council (1999) }\end{array}$ \\
\hline $\begin{array}{l}\text { Norway_carbon and sul- } \\
\text { phur dioxide taxes }\end{array}$ & 1991-2007 & $\begin{array}{l}21 \% \text { reduction in } \mathrm{CO}_{2} \text { from power plants by } 1995,14 \% \text { national reduc- } \\
\text { tion in } \mathrm{CO}_{2} \text { in } 1990 \mathrm{~s}, 2 \% \text { attributed to carbon tax } 12 \% \text { reduction in } \\
\mathrm{CO}_{2} \text { emissions/unit of GDP }\end{array}$ & $\begin{array}{l}\text { OECD (2001) } \\
\text { OECD (2006) } \\
\text { Nordic council (2006) }\end{array}$ \\
\hline $\begin{array}{l}\text { Denmark-energy and } \\
\text { carbon tax }\end{array}$ & 1992 & $\begin{array}{l}\mathrm{CO}_{2} \text { emissions in affected sectors down by } 6 \% \text { and economic growth } \\
\text { up by } 20 \% \text { between } 1988 \text { and } 1997 \text { and a } 5 \% \text { reduction in emission } \\
\text { in } 1 \text { year in response to tax increase. In } 1990 \text { s a } 23 \% \text { reduction in } \mathrm{CO}_{2} \\
\text { from as usual trend and energy efficiency increased by } 26 \% \text { Subsidy } \\
\text { to renewable may have accounted for greater proportion of emis- } \\
\text { sions reductions than tax }\end{array}$ & $\begin{array}{l}\text { OECD (2006) } \\
\text { Nordic Council (2006) }\end{array}$ \\
\hline $\begin{array}{l}\text { Sweden-energy and car- } \\
\text { bon taxes }\end{array}$ & 1990-2007 & $\begin{array}{l}\text { Emissions reductions of } 0.5 \text { million tons per annum Emissions would } \\
\text { have been } 20 \% \text { higher than } 1990 \text { levels without tax }\end{array}$ & $\begin{array}{l}\text { Nordic council (2006) } \\
\text { Swedish Ministry of } \\
\text { Finance (MoF) (2004) }\end{array}$ \\
\hline $\begin{array}{l}\text { Nordic council 2006, Swedish } \\
\text { MoF } 2004\end{array}$ & 1999-2007 & $\begin{array}{l}\text { Emissions } 3.5 \% \text { lower than would have otherwise been Low tax rates } \\
\text { may have limited impact }\end{array}$ & $\begin{array}{l}\text { Finance ministry, The } \\
\text { Netherlands (2007) }\end{array}$ \\
\hline $\begin{array}{l}\text { Germany env tax reform, } \\
\text { taxes on transport, fuels } \\
\text { and electricity }\end{array}$ & 1999-2005 & $\begin{array}{l}\mathrm{CO}_{2} \text { reduced by } 15 \% \text { between } 1990 \text { and } 1999 \text { and } 1 \% \text { between } 1999 \\
\text { and } 2005 \mathrm{CO}_{2} \text { emissions 2-3\% lower by } 2005 \text { than they would have } \\
\text { been without tax German re-unification an important factor in reduc- } \\
\text { tions }\end{array}$ & $\begin{array}{l}\operatorname{EEA}(2007) \\
\operatorname{OECD}(2006)\end{array}$ \\
\hline UK-industrial energy tax & $2001-2010$ & $\begin{array}{l}\text { UK CO } 2 \text { emissions reduced by } 2 \% \text { in } 2002 \text { and } 2.25 \% \text { in } 2003 \text { and } \\
\text { cumulative savings of } 16.5 \text { million tonnes of carbon up to } 2005 \\
\text { Reduction in UK energy demand of } 2.9 \% \text { estimated by } 2010\end{array}$ & $\begin{array}{l}\text { Cambridge economet- } \\
\text { rics (2005) } \\
\text { HMT (2006) }\end{array}$ \\
\hline $\begin{array}{l}\text { Maharashtra-Tamilnadu State } \\
\text { Govt. GT on vehicles }\end{array}$ & $2005-2010$ & $\begin{array}{l}\text { Though effect as whole has not been quantified but govt has earned } \\
\text { above Rs } 300 \text { crore annually and it is constantly increasing }\end{array}$ & $\begin{array}{l}\text { Srivastava and Rao } \\
\text { (2010) }\end{array}$ \\
\hline
\end{tabular}

Source Green Fiscal Commission 2009; Qayum and Gupta (2014)

an entirely different set of socio-economic and political realities. Common environmental taxation system may not suit worldwide. However, a cross border adjustment of taxes may be legally done to sort out the differences under the initiatives of world trade organization (WTO). Though, it is a complex and a tough task, but still it can be achieved if countries come forward and demonstrate a collective political will. The corporate social responsibilities (CSR) for various sectors, industries (which are major pollutant contributor) may also be ascertained as the CSR will not only bring reduction in hazardous emissions but also generate avenues for financial gains for the big giants by tax incentive mechanism and ethical rationale of saving the planet for the humanity cause. The integrated approach offers immense scope towards achieving dual objective of conserving environment and earning means against normal levied green taxes.

\section{Taxation policy for other polluting activities}

It may be extended to other industries listed in Fig. 4 e.g. for petroleum fuel; vehicles may be checked at various petrol filling stations/outlets having pollution level certifying arrangements. Carbon emission level of each vehicle may be examined on monthly/half yearly basis. There is well defined permissible carbon emission level [Central
Pollution Control Boards (CPCB) 2000] for all types of vehicles. All the defaulters emitting above the permissible limits shall be fined with green taxes. For detailed tax slabs emissions above permissible level may be categorized for differential tax rates and progressive rate of taxation shall be followed to motivate people to emit less and to get tax benefits. It was found that progressive taxation rates possess inherent trait of motivation for industries and other sectors to reduce its carbon emission (Gupta et al. 2015).

\section{Green tax determination: problems and remedies}

Pigouvian tax implementation requires both marginal abatement information and marginal damage functions. When one of the consumption commodities generates an externality, it was found how the well known optimal commodity tax formula of Ramsey is altered (Bovenberg and Frederick 1994). Later, in a general equilibrium framework optimal environmental taxation in the presence of other taxes was examined. It was derived when other distortionary taxes are present, how optimal environmental tax rates deviate from rates implied by the Pigouvian principle. Green taxation based public policy must have dimensions including; coherence of public with the policy, public must believe that it is 

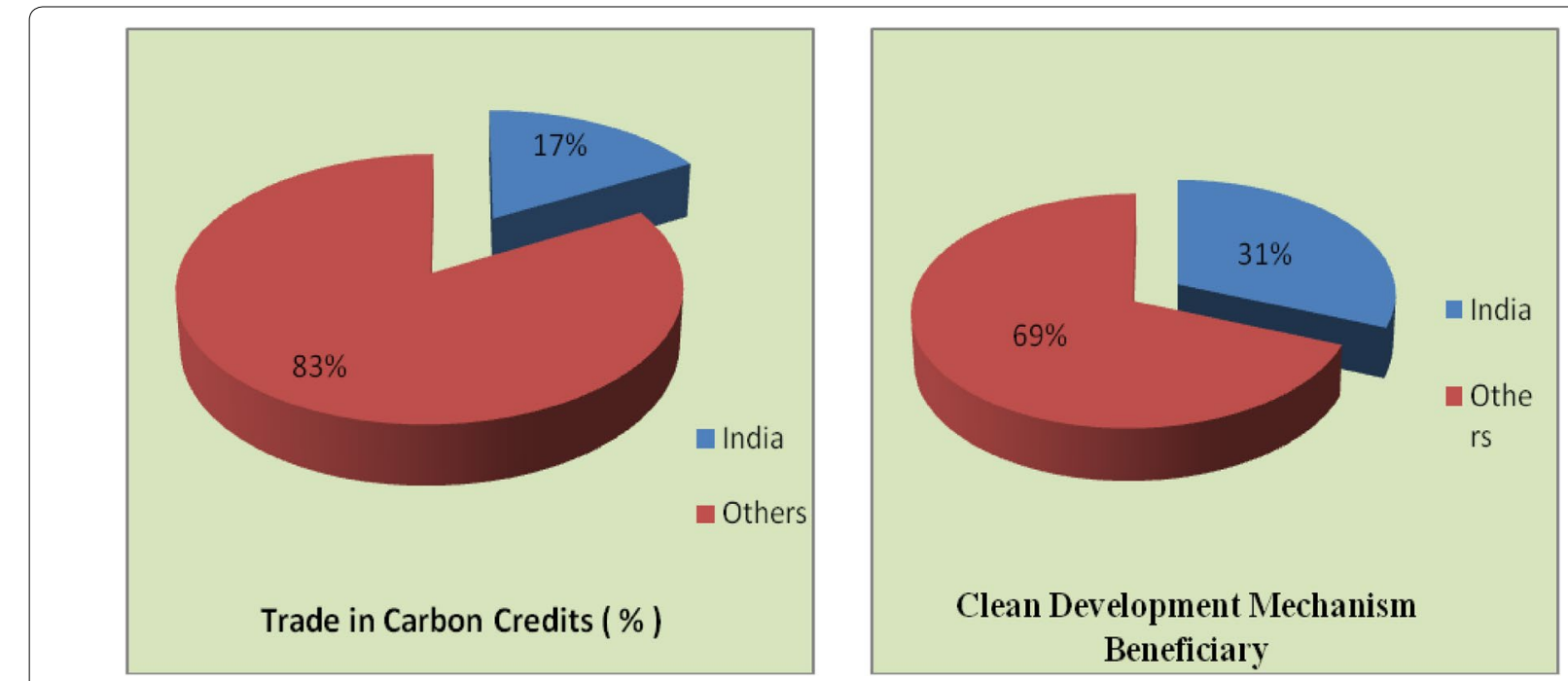

Fig. 3 India's share in global climate change

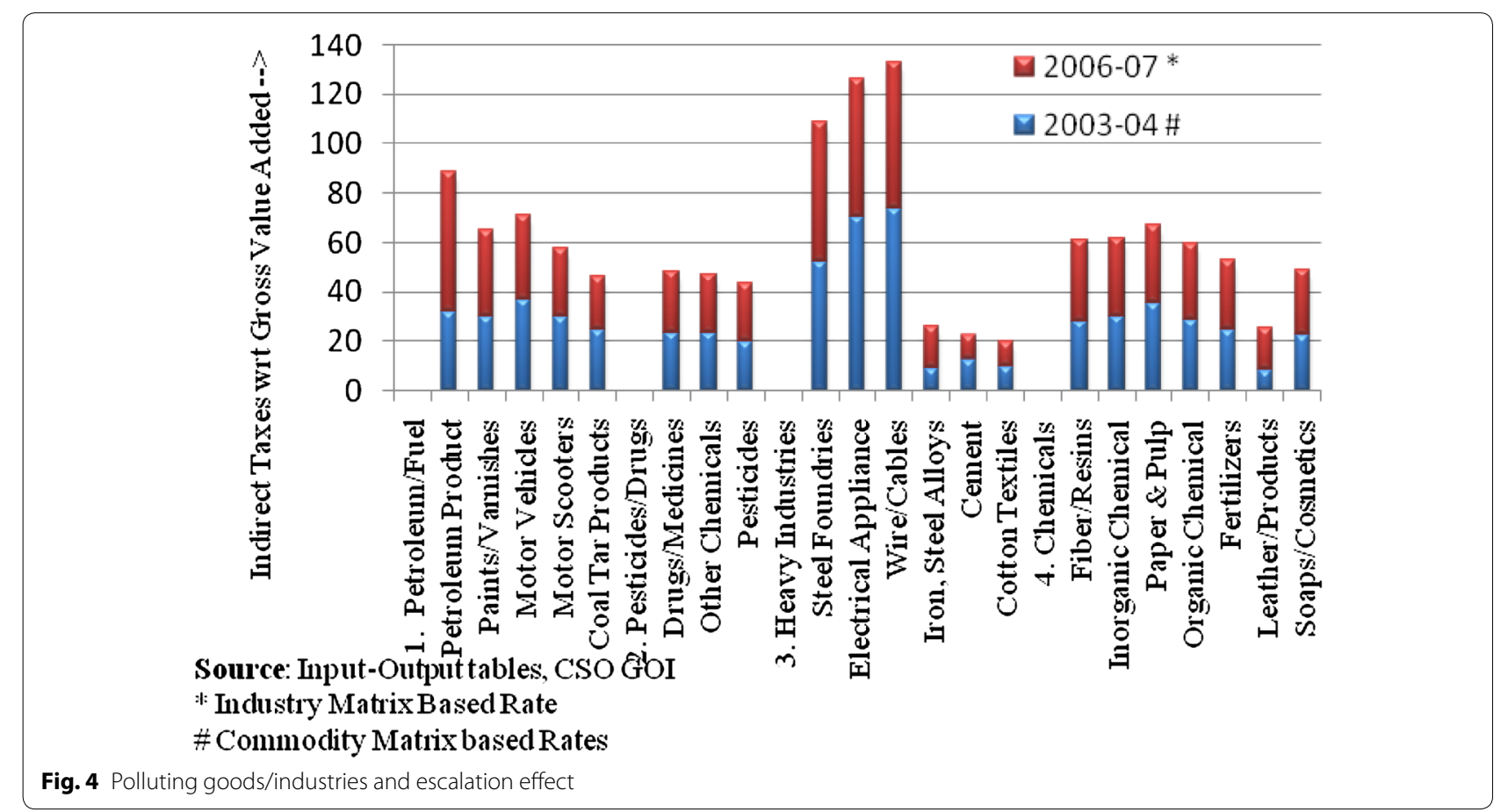

implementable and government is committed for its implementation. The public may be unaware of environmental impacts of their purchases and hence qualitative aspect of this awareness factor must be accommodated in the environmental policy framework which even Ramsey formula failed to address as it lacks quantifiability.

It was deciphered from the numerical model that optimal carbon tax rates are between 6 and $12 \%$ below the marginal environmental damages (Bovenberg and Goulder 1996). The effects of green taxes are very often neglected and it is difficult to work out when important polluting goods like coal, fertilizers and petroleum are characterized by administered pricing regimes and obscure policy of subsidies. Transparent subsidy regime and market determined prices are necessary and sufficient conditions for working out an effective and efficient green taxation model. Otherwise, it may create some sort of distortion in the market and may not be in synchronicity with the free market economy. The immediate benefits of green taxation is accrued locally rather globally 
but its long term repercussion is global in nature. For example, a carbon tax can ensure improvements in local air quality prominently than any major reduction in the global emissions. Market is far more competent than the government in bringing a large scale innovation in clean technology and energy efficiency. Thus, the market must be involved while investing back the collected green taxation money into renewable and clean energy.

Another major problem is the resistance of environmental fiscal reforms because of the assumption that it would slow down the economic growth as it is energy intensive and green taxation will make them costlier. It is also believed that such move would mobilize business and market to come up with innovative solutions to enhance energy efficiency of business and industrial processes which could lead to an overall improvement into the energy intensity. However, studies have shown the effect of tax reform with the green shift may have positive effect on employment and a negligible adverse effect on the growth and it will lead to sustainable economic growth (Ekins 2009). It is very likely that green taxation would transform energy intensive economy to a low carbon economy especially for the developing nations.

\section{Conclusion}

Adoption of green taxation may increase the price of energy and it is considered to be a critical intervention for achieving the GHGs emission reduction targets as per Kyoto obligations. This shall lead to reduced demand of energy and better environmental conservation practices. It is often articulated that carbon tax may be detrimental for economy because with increasing price of energy, the price of commodities would also escalate. Thus, it may reduce demand in the economy. It would raise the cost of entrepreneurship and as result; there might be exodus of a large number to businesses to other countries which provide a favorable tax regime. It sucks money out from the existing economy system. Despite all, carbon tax system would be favored since it is less-complex, predictable, transparent, accountable and much easy to monitor. It avoids speculation, inconspicuousness and extreme volatility which is usual with the other tax regimes. The Carbon tax is easy to monitor because it can be easily embedded into an existing system of taxation. Moreover, a carbon tax could contribute to social redistribution because the collected tax could be invested back into renewable energy and clean energy endeavors. Developing nations are in dire need of greening their economy in wake of much anticipated legally binding global emission reduction treaty, which is likely to be agree upon and implemented by 2020 . Through carbon tax, government taxation mechanism can target carbon emissions. Countries should develop their capacities in environment concerning industries where there is a scope of considerable expansion of demand rather than concentrating on polluting industries where there is considerable excess capacity in advance.

The emergence of industrial revolution led to one of the biggest century long global problem of environmental pollution. It is the environment which is much more talked among people of different classes and peoples of various walks of life. Consequently, various international treaties, accords, conventions were established; ratified and re-affirmed in the last few decades. At later stage these factors were mapped to be major factors for the environmental pollution. Further, at the cost of environment degradation development and sustainable economic growth cannot be achieved. Taxation will be a deterrent towards this environmental degradation and optimal energy utilization endeavors. The integrated modeling based approach offers immense scope towards achieving environment conservation and earning means against levied green taxes. It generate new hopes for optimizing profits by reducing the amount on the basic expenditures in form of tax incentives and it is anticipated that industries will get motivated in bringing efficient technology base. Further, environmental taxation is inevitable irrespective of the fact that a nation is developing or among developed nations.

There are issues in applying environmental taxation especially is a developing country as it has possible threat of affecting the developmental rates and it is least likely that it will be welcomed by the concerned people. However, it must go a long way if human civilization is to be saved from environmental catastrophe of climate change which is likely to happen because of industrial effluents including emission of GHGs, carcinogenic and other pollutant entry or rapid loss of biodiversity. The current rapid degradation of environment scenario demands novice legislation and stringent laws to enhance the compliance of various parties including industries and people. There are several heavy industries such as iron, steel foundries, electrical appliances, steel alloys, cement industries etc. that have ever lasting impacts on environmental health. The policy of GT can be exploited to its full potential as a tool to curb and mitigate the hazardous impacts. The approach may be used for various other industries like medical industry in terms of environmental damages caused by the medical waste to find out its environmental impact or for the ill effects of nuclear waste generated. The policies could be and should be designed to bring out optimal contribution of these industries towards generating resources for socio-economic growth and in addition, the industries in non-compliance with TERI criteria at large scale will be monetarily contributing which may be utilized towards bridging the gap for UNFCCC 'Green Climate Fund' which is due for 2020. 


\section{Authors' contributions}

AQ proposed the idea, made analysis, drafted the manuscript and implemented the idea. AnG made critical evaluation and provided continuous feedbacks. AkG collected related data and she did the analysis. RA was responsible for establishing link between environmental law and socio-economy factor based development requirements. All authors read and approved the final manuscript.

\section{Author details}

1 Department of Environment and Forest, Govt. of Arunachal Pradesh, Itanagar, India. ${ }^{2}$ Department of Chemistry, Deen Dyal Upadhyay University, Gorakhpur, India. ${ }^{3}$ Centre for West Asian Studies, Jawaharlal Nehru University, New Delhi, India. ${ }^{4}$ Centre for the Study of Regional Development, Jawaharlal Nehru University, New Delhi, India.

\section{Acknowledgements}

Author acknowledges the support received from Indira Gandhi National Forest Academy (IGNFA), Dehradun India. We would like to thank Mr. Pradeep Mishra, IFS for his valuable inputs and constant support towards bringing out the current work and also to the Ministry of Environment, Forest and Climate Change, New Delhi for providing such opportunity of independent and free hands on research.

\section{Competing interests}

The authors declare that they have no competing interests.

Received: 18 March 2016 Accepted: 21 September 2016

Published online: 18 October 2016

\section{References}

Baumol WJ, Oates WE (1988) Theory of environmental policy, 2nd edn. Cambridge University Press, Cambridge

Bovenberg AL, Frederick VDP (1994) Consequences of environmental tax reform for involuntary unemployment and welfare: CESifo working paper series

Bovenberg AL, Goulder LH (1996) Optimal environmental taxation in the presence of other taxes: general equilibrium analyses. Am Econ Rev 86(4):985-1000

Cambridge econometrics (2005) Modeling the initial effects of the Climate Change Levy. http://www.hmrc.gov.uk. Accessed 12 Dec 2014

Central Pollution Control Boards (CPCB) (2000) Central Motor Vehicles Rules, 1989 GSR 77 (E). http://cpcb.nic.in/Industry-Specific-Standards/Emission/ MotorVehicles.pdf. Accessed 5 Jan 2015

EEA (2007) Greenhouse gas emissions: trends and projections in Europe. EEA Report No 5/2007. http://www.reports.eea.europa.eu/eea_ report 2007 5/en. Accessed 12 Dec 2014

Ekins P (2009) Resource productivity, environmental tax reform and sustainable growth in Europe. Conference of the PETRE project, Anglo-German foundation for the study of industrial society

Finance ministry, The Netherlands (2007) de Jaeger: presentation at the Brussels tax forum-2007. State Secretary for Finance, The Netherlands

Fullerton D, Leicester A, Smith S (2008) Environmental taxes. National bureau of economic research 14197

Green Fiscal Commission (2009) The case for green fiscal reform, London UK. http://www.greenfiscalcommission.org.uk/index.php/site/about/ final_report. Accessed 10 Dec 2014

Griha (2010) Introduction to national rating system, ministry of new and renewable energy, Government of India, the energy and resources institute vol-1
Gupta A, Mariswamy T, Qayum A, Prajna GS (2015) Hybrid model of environmental taxation: transition from European to Indian carbon tax to energy trade scheme. Environ Conserv J 16(1\&2):19-24

Gurkan SK (2003) Environmental taxation and economic effects: a computable general equilibrium analysis for Turkey. J Policy Model 25:795-810

HMT (2006) The Climate Change Levy package. HM Treasury, London. http:// www.hmttreasury.gov.uk/media/8/B/bud06_climate169.pdf. Accessed 12 Dec 2014

John P, Paul R (1974) Human population and the global environment: population growth, rising per capita material consumption, and disruptive technologies have made civilization a global ecological force. Sigma Xi, Sci Res Soc 62(3):282-292

Mani M (2013) Greening India's growth: costs, valuations and trade-offs. Routledge Publisher Milton Park, Abingdon, p 97

McDevitt TM (1996) World population profile. US Department of commerce, bureau of the census, vol 3, p 14

Nair S, Nandakumar P (2013) Environmental carbon trading scenario in india: a global issue of 21st century: a review. Int J Adv Res Technol 2(9):110-118

Narula R, Dunning JH (2000) Industrial development, globalization and multinational enterprises: new realities for developing countries. Oxf Dev Stud 28(2):141-167

Newell RG, Pizer WA, Raimi D (2012) Carbon markets: past, present, and future. Washington DC resources for the future, RFF DP 12-51, p 29

Nordic council (1999) The use of economic instruments in Nordic environmental policy 1997-1998. TemaNord 1999:524. Copenhagen, Denmark

Nordic council (2006) The use of economic instruments in Nordic and Baltic environmental policy 2001-2005. National Environmental Research Institute, Denmark

OECD (2001) Organisation for economic cooperation and development, environmentally related taxes in OECD countries: issues and strategies, Paris, France

OECD (2006) Organisation for economic cooperation and development, the political economy of environmentally related taxes. OECD, Paris

Qayum A, Gupta A (2014) Environmental taxation as a mitigation tool: a denovo approach. Environ Pol Law 44(3):312-321

Singh S, Deshwal M (2012) Green tax and its effectuation in India. Social science research network

Srivastava DK, Rao BC (2010) Reforming indirect taxes in india: role of environmental taxes. Madras School of Economics, Chennai

Sterner T (2007) Gasoline taxes: a useful instrument for climate policy. Energy Policy 35:3194-3202

Swedish Ministry of Finance (MoF) (2004) Sweden energy \& carbon taxes, Stockholm, Sweden

Symons E, Proops J, Gay P (1994) Carbon taxes, consumer demand and carbon dioxide emissions: a simulation analysis for the UK. Fisc Stud 15(2):19-43

United Nations framework convention on climate change (2011). Transitional committee for the design of the green climate fund

\section{Submit your manuscript to a SpringerOpen ${ }^{\circ}$ journal and benefit from:}

- Convenient online submission

- Rigorous peer review

- Immediate publication on acceptance

- Open access: articles freely available online

- High visibility within the field

- Retaining the copyright to your article

Submit your next manuscript at springeropen.com 